\title{
Agricultural Sector Investment on Gross Domestic Regional Product (GDRP) in West Java 2007-2012
}

\author{
Ratni Heliati \\ Universitas Padjadjaran \\ ratniheliati@yahoo.com \\ Yovino Dwiputra \\ Universitas Padjadjaran
}

\begin{abstract}
This study aims to determined the impact of investments in the agricultural sector to the Gross Domestic Regional Products (GDRP) of agriculture in West Java. The sample was taken from 26 regions in West Java. The results showed that Foreign Capital Investment (FCI) and Exchange rate have positive and significant impact to GDRP. Domestic Capital Investment (DCI) has positive effect of labor but not significantly to GDRP. BI Rate has significant negative effect on GDRP. Fixed effect model allows the analysis of individual securities to be interpreted as the position of the relative potency of a districts / cities. There are nine districts/cities that have a significant positive intercept. These districts are categorized as areas which contribute highly to agricultural sector. The highest sector is in Indramayu district, the second is in Sukabumi, Banjar, Subang and so on. Cimahi has the lowest score of intercept. Negative intercept is an area of low agricultural contribution, generally those which are categorized as industrial areas, such as Bandung, Cirebon, Bogor, Bekasi, Karawang. These areas are classified as industrial area which have negative contribution of agricultural sector to the GDRP.
\end{abstract}

Keywords: GDRP, Foreign Capital Investment, Domestic Capital Investment, Exchange Rate, BI rate.

\section{INTRODUCTION}

Indonesia is one of the agricultural countries which have greater potential in the agricultural sector. In the Medium Term Development Plan of the Ministry of Agriculture phase-3 (2015 - 2019), the agricultural sector is still an important sector in national economic development. The strategic role of agriculture depicted in its contribution in providing food and industrial raw materials, contributor to Gross Domestic Products (GDP), Foreign exchange earnings, the main employer, the main source of income for rural households, providers of feed ingredients and bioenergy, play an important role in efforts to reduce greenhouse gas emissions. Realization of national investment per sector in 2007-2011 is described as contained in Table 1.

Agricultural investment sent by the major capital owners are considered less beneficial for domestic and foreign investors. This happens because agricultural sector has a high risk of uncertainty which includes water availability, climate variability and the nature of policy. These responds to mitigate greenhouse emission and adapt to change that will intensify the traditional risks by farmers in managing and fluctuations in commodity markets (Mallawaarachchi, et.al.). The agricultural sector in West Java has contributed to increase foreign exchange earnings and is expected to encourage investors to invest in it. Contribution on national investment needed in 2007-2012 is describedas contained in Table 2.

Based on Central Statistics Agency (BPS) in 2006, the agricultural sector is a sector which absorbs highest labor for equally to $44.6 \%$. Their contribution to Gross Domestic Products (GDP) is only $13.3 \%$. The unbalance of GDP contribution and the amount of labor absorbed means that the level of labor productivity in the agricultural sector is the lowest. The industrial sector contributes $28.9 \%$ of national GDP with $12.1 \%$ labor absorption. As a result, the welfare of households working in agriculture is lower than those who are employed in industry (www.bappenas.go.id).

The agricultural sector is considered asa static sector and has a negative role in the economic growth for a country that plays an active role. Since 1980s, there was a significant change in thinking in public policy that sees the agricultural sector more positively. The sector is believed to play a role as a leader in the sector of economic development (Tambunan, 2010; Setiono 2010; Syafrizal, 2012; Refi, 2014). 
Gross Domestic Regional Product (GDRP) or better known as Regional Income is the statistics that summarize the acquisition of the value added of all economic activity in a region (PPSK, 2008). Gross Domestic Regional Product (GDRP) is calculated in two ways: (1) On the basis of current prices, (2) On the basis of constant prices. Gross Regional Domestic Product (GRDP) can be translated into three terms (www.bps. go.id), namely: (1)Production Approach, (2) Income Approach, (3) Expenditure approach. Agricultural sector contribution to GDRP in West Java showed a declining trend since 1975 by $34.6 \%$, in $199021.6 \%$ and in 2004 to $12.3 \%$. It was then switched to the industrial sector which contributes to the GDP amounted to $53.8 \%$ (Hill, 2008). Of contributions to GDRP of agriculture sector in West Java in 2014 to $8.73 \%$ was below the processing industries amounted to $43.61 \%$ and trade, hotels and restaurants $15.25 \%$ (West Java in figures, 2015).

Investment (Subandi, 2012) is the expenditure made by investors concerning the use of resources such as equipment, buildings, production equipment, and other new machines or supplies that are expected to benefit from the investment. Foreign Capital Investment (FDI) is an investment made by a company in one country to a company in another country. It is then intertwined relationships between companies holding with its affiliated companieswhich are collectively referred to as Transnational Corporation (TNC).

Domestic Investment (DCI) is the investment activity which conducts business in the territory of the Republic of Indonesia (NKRI) carried out by a domestic investor using domestic capital. Investment provisions are stated and regulatedin the Law No. 25 Year 2005 regarding Investment. Domestic Capital Investment can be carried out by individuals Indonesian Citizen (WNI), entity, or government investments in the territory of the Republic of Indonesia (NKRI).

The definition of labor forces people to work. It also consists of those people who are either ready to work or working. Exchange rate is the price of one country's currency to another country's currency rates (Mishkin, 2008). BI Rate, or interest rate set by Indonesian Bank, maintains the stability of monetary rate. The policy of $\mathrm{BI}$ interest rate reflects the attitude or stance of monetary policy set by Bank Indonesia (BI) which is also announced to the public. Operationally, the monetary policy stance is reflected by the policy-setting interest rate (BI Rate) which is expected to be able togive influenceon money market interest rates and deposit rates and bank lending rates.

The theory of economic growth is defined as an explanation of the factors in determining the expenditure increase (output) per capita in the long term, and an explanation of how these factors interact with each other, resulting in the growth process. Here are some opinions from the theory of economic growth (Skousen, 2001; Todaro, 2006; Daryanto \& Hafizrianda 2010; Kuncoro,
2013): (1) the first is theory of Solow-Swan. Economic growth depends on the increase in supply factors such as labor, capital accumulation and technology. The ratio of capital expenditure (output) can change if labor is used larger, the amount of capital will be lesser. However, if the amount of capital used is greater, the amount of labor is needed less. (2) the second is theory of Harrod-Domar; an extension of the Keynesian analysis of national economic activity and labor problem. Keynesian analysis is considered incomplete because it does not address the economic problems inlong term. HarrodDomar analyzes regarding the necessary conditions therefore the economy can grow and continue to thrive in the long term very well (steady growth).

Currently, there is no single theory which could explain the economic development of the region in a comprehensive manner, however several theories (individual) canpartially help the importance of regional economic development and the factors that give influence to it. Jamzani Sodik and Didi Nuryadin (2005) conducted a study on the investment and economic growth (a case study in 26 provinces in Indonesia, pre- and post-autonomy), using the method of General Least Square (GLS). Dependent variables Gross Domestic Regional Product (GDRP) and the independent variables of Foreign Capital Investment (FCI), Domestic Capital Investment (DCI), labor force, inflation, exports, importsare described in the model specification as followed:

$$
\begin{aligned}
& \mathrm{GDRP}_{\mathrm{it}}=\alpha_{0}+\beta_{1} \mathrm{FCI}_{\mathrm{it}}+\beta_{2} \mathrm{DCI}_{\mathrm{it}}+\beta_{3} \mathrm{LF}_{\mathrm{it}}+\beta_{4} \mathrm{INF}_{\mathrm{it}}+ \\
& \beta_{5}(\mathrm{X}-\mathrm{M})_{\mathrm{it}}+\boldsymbol{\varepsilon}_{\mathrm{it}}
\end{aligned}
$$

This study is using panel data regression of 26 provinces during 1998-2003. It also uses the indication of domestic and foreign influence on regional economic growth. The net export effect is relatively small,while the inflation rate has no effect on regional economic growth on the observation period 2000-2003 (after the regional autonomy), where as prior to negative effect.

The study of Anita Faiziah and Sofyan (2014) about the influence of the amount of labor, exports, investment 
and bank credit to the agricultural sector GDRP Aceh province is described with the model specification as follows:

$$
\begin{aligned}
& \text { GDRPp }=\alpha+\beta_{1} \mathrm{Am}+\beta_{2} \mathrm{Xa}+\beta_{3} \mathrm{Ai}+\beta_{4} \mathrm{Ca}+\varepsilon \\
& \text { Description of variables: } \\
& \text { GDRPp }=\text { Gross Domestic Regional Product agricultural } \\
& \text { sector Aceh } \\
& \text { Am }=\text { The number of agricultural manpower Aceh } \\
& \mathrm{Xa}=\text { The export value of agricultural sector } \\
& \mathrm{Ai}=\text { Agricultural investment } \\
& \mathrm{Ca}=\text { Total bank credit agricultural sector } \\
& \alpha=\text { constants } \\
& \beta_{1,2,3,4}=\text { regresion coefficient } \\
& \boldsymbol{\varepsilon}=\text { error }
\end{aligned}
$$

The study of multiple linear regression of time series datain1999-2012 gave the result that labor had significant negative effect on exports and significant effect and investment. Meanwhile, bank credit gave positive and significant impact to GDRP.

This study describes the relationship of how GDRP influenced by investment, foreign and domestic, labor, exchange rate and interest rate in West Java (Figure 1). Hypothesisis describedas followed:

1. Foreign Capital Investment (FCI), Domestic Capital Investment (DCI), Labor, and rupiah exchange rate have positive influence on Gross Regional Domestic Regional Product (GDRP) in West Java.

2. BI Rate has negative effect on the Gross Domestic Regional Product (GDRP) in West Java.

\section{METHOD}

Method used in this study is descriptive and quantitative analysis. It aims to find out the investments allocated and the influence of the agricultural sector to GRDP investment in West Java in 2007-2012. Secondary data sources in 2007-2012 were taken based on the types of panel data. Data was obtained from Promotion Coordination Board (BKPM) West Java Province, the National Socio-economic Survey (Susenas), the Central Statistics Agency (BPS), the Asian Development Bank (ADB), and Bank Indonesia (BI), with linear regression multiple use Ordinary Least Square (OLS) software Stata version 12 (Apriliawan, 2013).

Based on studies conducted Jamzani Nuryadin Sodik \& Didi (2005), and Anita Faiziah \& Sofyan (2014), the authors apply the model to make modifications to the model. This study uses panel data from the years 2007 2012 with the research model as followed:

$\operatorname{LnGDRP}_{i t}=\beta_{0}+\beta_{1} \operatorname{LnFCI}_{\mathrm{it}}+\beta_{2} \operatorname{LnDCI}_{\mathrm{it}}+\beta_{3} \mathrm{LnL}_{\mathrm{it}}+$ $\beta_{4} \operatorname{LnER}_{\mathrm{it}}+\beta_{5} \mathrm{BIR}_{\mathrm{it}}+\varepsilon_{\mathrm{it}}$

Method test of panel data estimation is using Chow
Description of variables:

$$
\begin{array}{ll}
\text { GDRP } & \text { Gross Domestic Regional Product agricultural } \\
& \text { sector } \\
\text { FCI } & \text { Foreign Capital Investment agricultural sector } \\
\text { DCI } & =\text { Domestic Capital Investment agricultural sector } \\
\text { MP } & =\text { Manpower agriculture } \\
\text { ER } & =\text { rupiah exchange rate } \\
\text { BIR } & =\text { BI Rate } \\
\mathrm{i} & =\text { Regionsstudied } \\
\mathrm{t} & =\text { Years studied } \\
\beta_{0}= & \text { Intercept } \\
\beta_{1,2,3,4}= & \text { Parameter Variable } \\
\boldsymbol{\varepsilon} & =\text { Error Term }
\end{array}
$$

Test, Lagrangian Multiplier (LM) Test, Hausman Test and classical assumption test using Multicollinearity, Heteroskidastity test, autocorrelation test. Statistics test includes t-statistical test, z-statistic test, the coefficient of determination $\left(\mathrm{R}_{2}\right)$, and Sensitivity test (Enders, 2010).

\section{RESULT}

Chow Test (Table 3 ) aimed to see the results of $F$ probability of Fixed Effect (FE). It is the probability value where Alpha is less than 0.05 or $5 \%$ on significant level and $\mathrm{H}_{0}$ is rejected. The results of $\mathrm{F}$ probability of Fixed Effect (FE) on Chow Test is at 0.0000 , hence Chow test states that the best model is the model Fixed Effect (FE).

Lagrangian Multiplier (LM) (Table 4) Test is done by looking at the probability of Alpha chibar2 with a significance level of $5 \%$, while $\mathrm{H}_{0}$ is rejected. The results showed that the probability chibar2 Lagrangian Multiplier (LM) Test is at 0.0005 , while Hausman Test states that the best model is Fixed Effect(FE).

Hausman Test (Table 5) is performed by seeing the results of the probability of Alpha chi2 with a significance level of $5 \%$, while $\mathrm{H}_{0}$ is rejected. The results showed that the probability of Hausman Test is at 0.0105 , while the test itself showed the best model is the model of Fixed Effect (FE).

Multi-collinearity test (Coefficient of Correlation Between Independent Variables) is performed with a partial correlation matrix (people) among regressors (Correlation Coefficient Matrix). In Table 6, it can be seen the relationship between independent variables. Based on the rule of thumb $(0.80)$, there is no multicollinearity in the model because all the independent variables were below 0.80 .

In Table 7, it shows that in hetero-scedasticities, the test conducted by Wald by looking at the results of the probabilityis bigger than chi 2 with Alpha significance level of $5 \%$, while $\mathrm{H}_{0}$ is rejected. The results probability is also bigger than chi2 of the Wald test which the result 
was 0,000 , hence the test of hetero-scedasticity states thatit has problems heteroscedasticities.

In Table 8, it shows that the auto-correlation conducted by Wooldrige Test by looking at the results of Probis bigger than Alpha $\mathrm{F}$ with a significance level of $5 \%$, while $\mathrm{H}_{0}$ is rejected. The results Probis bigger than $\mathrm{F}$ from Wooldridge test which the result is at 0.0000 , hence the auto-correlation test states that it has a problem of autocorrelation.

BLUE assumption collision that occurred on Fixed Effect method is done in a way to treatment Fixed Effect using GLS (Generalized Least Square). According to Gujarati (2009), it is stated that GLS is an estimate of the BLUE for the model estimation method with GLS which has fulfilled the conditions ideal. As for the method of Random Effect, it does not do treatment because ofthe GLS method assumes that the individual errors are not correlated, as well as a combination therefore the estimation error will be more efficient and better generated model (Baltagi, 2005). The results of treatment using the GLS is described as contained in Table 9. It can be seen that the results of the regression using GLS prove that the factors which violates the assumption BLUE (Best Linear Unbiased Estimate) has been eliminated. By using GLS in this study, the absence of hetero-scedasticity or homo-scedasticity, and the absence of autocorrelation (no autocorrelation) are perfectly shown up.

T-statistic (Table 10) is used to determine whether there is influence of the independent variables individually (partial) fixed to variable. This test is performed by comparing the value of the t-stat with tables using a t-test one direction. The results of the $\mathrm{t}$-statistic for the model showed (Table 11) that (1) there is positive and significant effect on Foreign Capital Investment in agricultural sector, (2) Domestic Capital Investment in agricultural sector does not significantly give effect on agricultural laborers. It also had no significant effect, (3) there is positive and significant impact on foreign exchange (4) BI Rate gives significant negative effect on GDRP of agriculture in West Java. Test of F-statistic (Table 11) is also used to determine whether there is influence of the independent variables as a whole (global) fixed to variable. This test is performed by comparing the value of Prob $>$ chi2 the F-table. Based on the test results calculations, the F-statistics generated by Probis bigger than $>$ chi2 (Table 12), while the obtained results isat 0.0000 . Therefore, as a test of the overall variable Foreign Capital Investment (FCI), Domestic Capital Investment (DCI) in agriculture, agricultural laborers, exchange rate, and the BI Rate have simultaneously a significant effect on the variable Gross Domestic Regional Product (GDRP) of agriculture in West Java.

This test conducted to measure the variation of the value of the dependent variable can be explained by variations in the value of the independent variable. The coefficient of result determination (R2) of the selection panel models has been determined. It is the coefficient of determination of the test Fixed Effect (FE) which was also within the amount of 0.9500 . This shows that every additional independent variable, hence variation of the independent variables in the model is able to explain the variation in the dependent variable by $95 \%$, while the remaining $5 \%$ is explained by other variables outside the model (Table 14).

Interpretation and analysis of the results of estimationare described as followed:

(1) Foreign Capital Investment (FCI) has positive and significant effect on GDRP amounted to 0,1229657

(2) Domestic Capital Investment (DCI) has positive and insignificant effect on GDRP amounted to 0.0434732 .

(3) Labor have positive and insignificant effect on GDRP amounted to 0.152439 .

(4) Exchange Rate has positive and significant influence on GDRP amounted to 4.413201.

(5) BI rate has negative and significant effect GDRP amounted to 1.550976 .

The study by Sodik and Nuryadin (2005)stated that Foreign and Domestic Investment gives affects to the regional economic growth. Izuchukwu (2011) finding reveals that there is a positive relationship between Gross Domestic Product (GDP) and three independent variables (Domestic Saving, Government Expenditure on Agriculture and Foreign Direct investment in Agriculture). The study of Faiziah and Sofyan (2014) indicated that the investment give effect on GDRP. Results from Maqin (2011) showed that the electric infrastructure, manpower and development expenditure have positive and significant impact to GDRP. The study of Utomo, et. al. (2015) showed that investment in the agricultural sector will be able to enlarge and expand its production capacity in East Java, including raising the economy impact on the formation of income/ salaries for workers. The study of Novita et. al. (2009) showed that the impact of agricultural investment is happening to the formation of the output, income, and the creation of employment. Meanwhile, the study of Lenggogeni (2012) showed that the exchange rate significantly gave influences to the agricultural sector investment.

There is a difference between this study and the previous ones. The difference is that domestic capital investment and manpower has no significant effect on GDRP. This can happen because GDRP of West Java is dominated by the manufacturing / processing. The lowincreasing contribution of agriculture to GDRP in West Java occur based on the phenomenon of high-ranked poverty in Indonesia related to the agricultural sector (Suryahadi and Gracia, 2011). Domestic investors and manpower are not interested in investing or working in the agricultural sector, due to the perception of poverty 
and risk.

Fixed effect model allows the analysis of the individual effect of each district/city to be interpreted as the position of the relative potency of a district/town area of the district/city. Interceptof each district/city means that if there is no influence of all independent variables, the GDRP in each district/city was respectively in accordance with the value of intercept (Table 15). There are nine districts/cities that have a positive intercept and remain negative.

Positive intercept indicates that districts/cities have higher GDRP than the other. Highest intercept value was in Indramayu (1.438182). It meant that the heterogeneity compared to other districts/cities can encourage higher GDRP. Positive intercepts indicate that the pointed areas highly contributed to farm. Lowest intercept value was in Cimahi (-3.931598). Negative intercept is an area of low agricultural contribution, generally those which are categorized as industrialer services areas, such as Bandung, Cirebon, Bogor, Bekasi, Karawang. Therefore, these are areas of industrial/service which give negative contribution in agricultural sector to GDRP.

\section{CONCLUSION}

The study uses panel data from 26 regencies/cities in West Java from 2007-2012. The conclusions are:

1. Foreign Capital Investment (FCI) has a positive and significant effect in improving the agricultural sector GDRP in West Java.

2. Domestic Capital Investment (DCI) is positive but not significant effect in improving the agricultural sector GDRP in West Java

3. Labor have not significant positive effect but improving the agricultural sector GDRP.

4. Exchange rate have positive and significant effect in improving the agricultural sector GDRP in West Java.

5. BI Rate have negative and significant effect on GDRP.

In improving the agricultural sector in West Java. Advice to authors based on the results of this research to:

1. Central Government:

a. Foreign Capital Investment (FCI) is enhanced to boost regional economic growth by facilitating the investors to invest in the agricultural sector in particular.

b. Domestic Capital Investment (DCI) is suppposedto compensate foreign investment, especially in agriculture by always doing $\mathrm{RnD}$ (Research and Development) in order to create improved clones or processed products. Therefore, domestic/local investors will be interested in investing to the agricultural sector.

2. Bank Indonesia: a. Setting a BI policy in accordance with the safe limit to investors interested in investing.

b. Stabilization of the exchange rate for the purposes of agricultural inputs.

3. It is necessary to increased productivity and quality of labor, in order to increase investment opportunities in the agricultural sector.

\section{REFERENCES}

Apriliawan, Dody, dkk. 2013. Permodelan Laju Inflasi Di Provinsi Jawa Tengah Menggunakan Regresi Data Panel. Jurnal Gaussian, Vol. 2, No. 4.

Baltagi, B. H., Bratberg, E., \& Holmås, T. H. 2005. A panel data study of physicians' labor supply: the case of Norway. Health Economics, 14(10), 1035-1045.

Daryanto, Arief. \& Hafizrianda, Yundy. 2010. Model-Model Kuantitatif Untuk Perencanaan Pembangunan Ekonomi Daerah: Konsep Dan Aplikasinya. Bogor: IPB Press.

Enders, Walter. 2010. Applied Econometric Time Series. United State: John Wiley \& Sons, Inc.

Faiziah, Anita, \& Sofyan. 2014. Retrieved from Agrisep, Vol. 15, No.2: http://www.jurnal.unsyiah.ac.id/ agrisep/article/view/2097.

Gujarati, D.N., 2003. Basic Econometrics. 4th. New York: McGraw-Hill.

Gujarati, Damodar, N., \& Porter, Dawn, C. 2009. Basic Econometrics. New York: McGraw-Hill.

Izuchukwu, Oji-Okoro. 2011. Analysis of the Contribution of Agricultural Sector on the Nigerian Economic Development. World Reiew of Business Research. Vol. 1 No. 1 March. Pp 191 - 200.

Jawa Barat dalam Angka 2015. Pusdalisbang.jabarprov. go.id.

Kementerian PPN/Bappenas. 2013. Perkembangan Ekonomi Indonesia.Laporan Perkembangan Perekonomian Indonesia Edisi Triwulan I Tahun 2013.

Kuncoro, Mudrajad. 2013. Mudah Memahami Dan Menganalisis Indikator Ekonomi. Yogyakarta: UPP STIM YKPN.

Lenggogeni, Susi. 2012. Retrieved from Jurnal Ekonomi, Vol. 20, No. 4:http://download.portalgaruda.org/ article.php? article $=106662 \& v a l=2268$.

Mallawaarachchi, Thilak; James Walcott; Neal Hughes; Peter Gooday; Lee Georgeson; Adam Foster. 2009. Promoting Productivity in the Agriculture and Food Sector Value Chain: Issues for R \& D Investment. Australian Government Bureau of Roral Science. Abare.go.au. December.

Maqin, R. Abdul. 2011. Pengaruh Kondisi Infrastruktur terhadap Pertumbuhan Ekonomi di Jawa Barat. Trikonomika. Volume 10, No. 1 Juni 2011. Hal 10-18.

Mishkin, Frederic, S. 2008. The Economic of Money, Banking, and Financial Markets. New Jersey: Pearson Education, Inc. 
Novita, Desi; Rahmanta; Kasyful Mahalli. 2009. Dampak Investasi Sektor Pertanian terhadp Perekonomian Sumatera Utara. Pendekatan Analisis Input-Output. Wahana Hijau. Jurnal Perencanaan dan Pengembangan Wilayah, Vol. 4 No. 3, April.

PPSK BI-LP3E FE-UNPAD.2008. Profil Dan Pemetaan Daya Saing Ekonomi Daerah Kabupaten/Kota Di Indonesia. Jakarta: Raja Grafindo Persada.

Refi, Wahyuni. \& Falahi, Ziyad. 2014. Desa Cosmopolitan Globalisasi dan Masa Depan Kekayaan Alam Indonesia. Jakarta: Change Publication.

Setiono, Dedi, N., S. 2010. Ekonomi Pengembangan Wilayah (Teori Dan Analisis). Jakarta: Fakultas Ekonomi Universitas Indonesia.

Sjafrizal.2012. Ekonomi Wilayah Dan Perkotaan. Jakarta: Rajawali Pres.

Skousen, Mark. 2001. Sang Maestro "Teori-Teori Ekonomi Modern”: Sejarah Pemikiran Ekonomi. Jakarta: Prenada Media Group.

Sodik, Jamzani. \& Nuryadin, Didi. 2005. Retrieved from Jurnal Ekonomi Pembangunan,Vol. 10, No. 2:http://journal.uii.ac.id/index.php/JEP/article/ viewFile/599/525.

Subandi.2012. Ekonomi Pembangunan. Bandung: Alfabeta.

Suryahadi, Asep dan Hadiwijaya, Gracia. 2011. The Role of Agriculture in Poverty Reduction in Indonesia. SMERU Research Institute. Jakarta Indonesia.

Tambunan, Tulus.2010. Pembangunan Pertanian Dan Ketahanan Pangan. Jakarta: Universitas Indonesia (UI-Press).

Todaro, Michael, P. \& Smith, Stephen, C. 2006. Economic Development. United Kingdom: Pearson Education, Ltd.

Utomo, Yohanna Kristanti, Badjuri, Teguh Hadi P. 2015. Dampak Investasi Sektor Pertanian terhadap Perekonomian Provinsi Jawa Timur. Pendekatan Analisis Input Output. Artikel Ilmiah Mahasiswa. Universitas Jember:

www.bappenas.go.id

www.bps.go.id

www.pertanian.go.id. Renstra Kementan Tahun 2015-2019

\section{APPENDIX}

Table 1. National Investment Realization Per sector (Billion Rupiah)

\begin{tabular}{ccccccc}
\hline \multirow{2}{*}{ Year } & \multicolumn{3}{c}{ FCI } & & \multicolumn{2}{c}{ DCI } \\
\cline { 2 - 7 } & Primary & Secondary & Tertiary & Primary & Secondary & Tertiary \\
\hline 2007 & $5,478.20$ & $42,935.28$ & $46,117.26$ & $4,377.40$ & $26,289.80$ & $4,211.50$ \\
2008 & $3,254.97$ & $43,792.74$ & $97,188.43$ & $1,757.70$ & $15,914.80$ & $2,690.80$ \\
2009 & $4,806.37$ & $39,804.75$ & $67,754.62$ & $4,415.90$ & $19,434.40$ & $13,949.50$ \\
2010 & $27,394.92$ & $27,956.71$ & $89,482.56$ & $12,327.40$ & $25,485.30$ & $22,813.60$ \\
2011 & $42,714.63$ & $59,459.13$ & $68,627.74$ & $16,306.90$ & $39,048.00$ & $20,645.70$ \\
\hline
\end{tabular}

Source: Capital Investment Coordination Board (BKPM)

Table 2. National Agricultural Sector Investment Requirements (Billions of Rupiah)

\begin{tabular}{ccccc}
\hline \multirow{2}{*}{ Year } & \multirow{2}{*}{$\begin{array}{c}\text { Economy } \\
\text { Growth (\%) }\end{array}$} & \multicolumn{3}{c}{ Agricultural Sector Investment Needs } \\
\cline { 3 - 5 } & 5,67 & $5,478.20$ & $4,377.40$ & $9,855.60$ \\
\hline 2007 & 5,74 & $3,254.97$ & $1,757.70$ & $5,012.67$ \\
2008 & 4,77 & $4,806.37$ & $4,415.90$ & $9,222.27$ \\
2009 & 6,14 & $27,394.92$ & $12,327.40$ & $39,722.32$ \\
2010 & 6,35 & $42,714.63$ & $16,306.90$ & $59,021.53$ \\
2011 & 6,28 & $55,691.81$ & $20,369.10$ & $76,060.91$ \\
2012 & &
\end{tabular}

Table 3. Chow Test Data Processing

\begin{tabular}{cc}
\hline Chow Test & Result \\
\hline Probability value F & Prob $>\mathrm{F}=0,0000$ \\
Decision & Fixed Effect \\
\hline
\end{tabular}

Source: Data Processing Results
Table 4. The Lagrangian Multiplier Data Processing (LM) Test

$$
\text { Lagrangian Multiplier }
$$$$
\text { (LM) Test }
$$

$\begin{array}{cc}\begin{array}{c}\text { Probability value Chibar2 } \\ \text { Decision }\end{array} & \text { Prob }>\text { chibar2 }=0,0005 \\ \text { Fixed Effect }\end{array}$

Source: Data Processing Results

Tabel 5. The Hausman Test Data Processing

\begin{tabular}{cc}
\hline HausmanTest & Result \\
\hline Probability valueChi2 & Prob $>$ chi2 $=0,0105$ \\
Decision & Fixed Effect \\
\hline Source: Data Processing Results &
\end{tabular}

Table 6. Testing Results Correlation Inter Independent Variables

\begin{tabular}{cccccc}
\hline & $\log (\mathbf{F C I})$ & $\log (\mathbf{D C I})$ & $\log (\mathbf{L})$ & $\log ($ Kurs $)$ & BI Rate \\
\hline $\log (\mathbf{F C I})$ & 1,0000 & & & & \\
$\mathbf{L o g}(\mathbf{D C I})$ & 0,2135 & 1,0000 & & & \\
$\mathbf{L o g}(\mathbf{L})$ & 0,0896 & 0,0328 & 1,0000 & & \\
$\mathbf{L o g}(\mathbf{E R})$ & $-0,0542$ & $-0,0438$ & $-0,0836$ & 1,0000 & \\
BI Rate & $-0,3713$ & 0,0578 & 0,1113 & 0,2114 & 1,0000 \\
\hline Source: Data Processing Results & & &
\end{tabular}


Table 7. Wald Test Result

\begin{tabular}{cc}
\hline WaldTest & Result \\
\hline Probability value Chi2 & Prob $>$ chi2 $=0,0000$ \\
Decision & Hetero-scedasticity \\
\hline
\end{tabular}

Source: Data Processing Results

Table 8. Wooldridge Test Result

\begin{tabular}{cc}
\hline WooldridgeTest & Result \\
\hline Probability valueF & Prob $>\mathrm{F}=0,0000$ \\
Decision & autocorrelation \\
\hline
\end{tabular}

Source: Data Processing Results

Table 9. Treatment Result with GLS (General Least Square)

\begin{tabular}{lcc}
\hline \multirow{2}{*}{ Variable } & \multicolumn{2}{c}{ General Least Square (GLS) } \\
\cline { 2 - 3 } & Coefficient & P-Value \\
\hline $\log (\mathrm{FCI})$ & 0,1229657 & 0,000 \\
$\log (\mathrm{DCI})$ & 0,0434732 & 0,210 \\
$\log (\mathrm{L})$ & 0,152439 & 0,502 \\
$\log (\mathrm{ER})$ & 5,43849 & 0,000 \\
BI Rate & $-1,425778$ & 0,000 \\
Cons & $-20,28129$ & 0,034 \\
Prob F & 0,0000 & \\
R-squared & 0,9500 & \\
\hline
\end{tabular}

Source: Data Processing Results

Table 10. Critical Limit Value Test t-statistic

\begin{tabular}{cccc}
\hline \multirow{2}{*}{$\begin{array}{c}\text { Degrees of } \\
\text { Freedom }(\mathrm{df}) *\end{array}$} & \multicolumn{3}{c}{$\alpha$ (one side) } \\
\cline { 2 - 4 } & $\alpha=0,1$ & $\alpha=0,05$ & $\alpha=0,01$ \\
\hline 20 & 2,528 & 1,725 & 1,325 \\
\hline
\end{tabular}

*df $=$ n-k $(26-6=20)$

$\mathrm{n}=$ observes amount (26)

$\mathrm{k}=$ Amount of parameter which used including constants (6)

Source: Gujarati (2003)

Table 11. T-statistic Test Result

\begin{tabular}{cccc}
\hline Variable & t-statistic & $\mathbf{H}_{0}$ & Note \\
\hline $\log (\mathbf{F C I})$ & 8,49 & Reject & Significant on $\alpha=5 \%$ \\
$\log (\mathbf{D C I})$ & 1,25 & Accept & NotSignificant on $\alpha=5 \%$ \\
$\log (\mathbf{L})$ & 0,67 & Accept & Not Significant on $\alpha=5 \%$ \\
$\log (\mathbf{E R})$ & 5,25 & Rejected & Significant on $\alpha=5 \%$ \\
BI Rate & $-26,09$ & Accept & Significant on $\alpha=5 \%$ \\
\hline
\end{tabular}

Source: Data Processing Results

Table 12. F-statistic Critical Boundary Value

\begin{tabular}{ccccc}
\hline $\mathbf{N} 2$ & $\mathbf{N} 1$ & \multicolumn{3}{c}{ F-table } \\
\cline { 3 - 5 }$(\mathbf{k}-\mathbf{1})$ & $(\mathbf{n}-\mathbf{k})$ & $\boldsymbol{\alpha}=\mathbf{0 , 1}$ & $\boldsymbol{\alpha}=\mathbf{0 , 0 5}$ & $\boldsymbol{\alpha}=\mathbf{0 , 0 1}$ \\
\hline 5 & 20 & 3,21 & 4,56 & 9,55 \\
\hline
\end{tabular}

N1 = df numerator $(\mathrm{k}-1 ; 6-1=5)$

$\mathrm{N} 2=$ dfdenumerator $(\mathrm{n}-\mathrm{k} ; 26-6=20)$

Source: Gujarati (2003)
Table 13. F-statistic Test Result

\begin{tabular}{lcc}
\hline Prob $>$ chi2 & $\mathbf{H}_{0}$ & Notes \\
\hline 0,0000 & Rejected & Significant on $\alpha=5 \%$ \\
\hline Source: Data Processing Results \\
\multicolumn{2}{c}{ Table } & 14. Result coefficient Determinant $\left(\mathrm{R}^{2}\right)$ \\
\hline \multicolumn{2}{c}{ Model Panel } & coefficient Determinant $\left(\mathrm{R}^{2}\right)$ \\
\hline Pooled Least Square (between) & 0,3933 \\
Fixed Effect (within) & 0,9500 \\
Random Effect (overall) & 0,6528 \\
\hline
\end{tabular}

Source: Data Processing Results

Tabel 15. Intercept value in each district/city in West Java Province

\begin{tabular}{clc}
\hline No & \multicolumn{1}{c}{ District or city } & Coefficient \\
\hline 1 & Bandung District & 0,0751325 \\
2 & Bekasi District & $-0,710196$ \\
3 & Bogor District & $-0,1449752$ \\
4 & Cianjur District & 0,2742127 \\
5 & Cirebon District & 0,5102275 \\
6 & Indramayu District & 1,438182 \\
7 & Karawang District & $-0,0865766$ \\
8 & Purwakarta District & $-0,7582612$ \\
9 & Subang Distric & 0,6002636 \\
10 & Sukabumi District & 1,084711 \\
11 & Sumedang District & 0,5399255 \\
12 & Bandung City & $-2,632238$ \\
13 & Banjar City & 0,9159898 \\
14 & Bekasi City & $-1,61832$ \\
15 & Bogor City & $-3,622806$ \\
16 & Cimahi City & $-3,931598$ \\
17 & Cirebon City & $-2,762146$ \\
18 & Depok City & $-1,839146$ \\
\hline & &
\end{tabular}

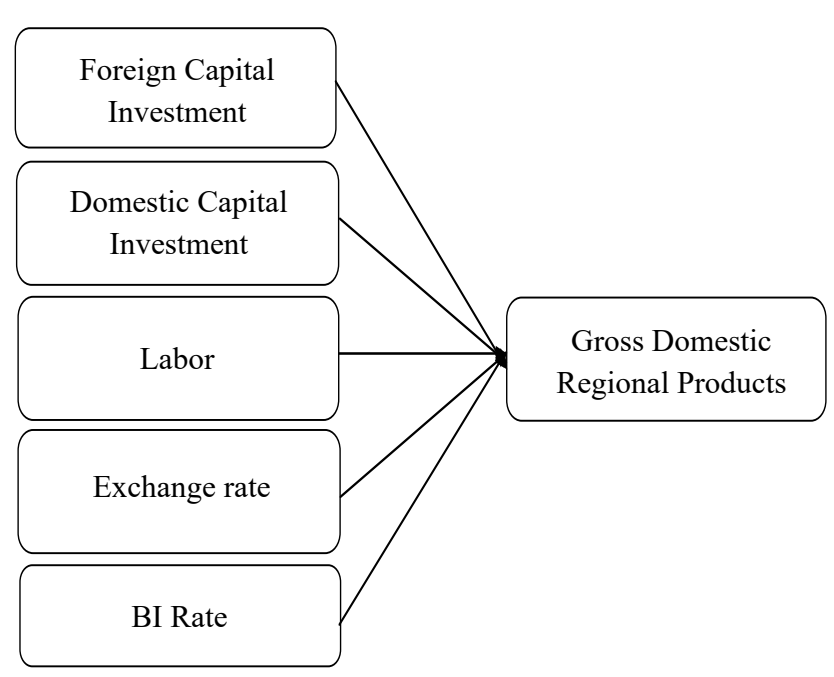

Figure 1. Framework 